\title{
Organic Catalysis in Oxidation of Isopropyl Alcohol by Pyridinium Flourochromate - A Kinetic and Mechanistic Study
}

\author{
KHUBI LAL REGAR and B. L. HIRAN \\ Chemical Kinetics and Polymer Research Laboratory, Department of Chemistry, University \\ College of Science, Mohan Lal Sukhadia University, Udaipur 313001, Rajasthan, India \\ aryakhubi@rediffmail.com
}

Received 23 January 2015 / Accepted 13 February 2015

\begin{abstract}
The kinetics of co-oxidation of isopropyl alcohol with oxalic acid by pyridinium flourochromate in perchloric acid-water medium leads to the formation of acetone and carbon dioxide. The reaction is first order with respect to [PFC], [Oxalic acid] and [IPA] and second order with respect to $\left[\mathrm{HClO}_{4}\right]$. Michaelis-Menten type kinetics was observed with respect to oxalic acid. The rate of co-oxidation of IPA and oxalic acid is hundred times greater than the combined rate of addition of both compounds separately. Oxalic acid catalyzed oxidation of IPA. The reaction rates were determined at different temperatures $(303,308,313,318$ and $323 \mathrm{~K}$ ) and the activation parameters were calculated. The reaction does not induce polymerization of acrylonitrile, this suggests PFC act as two electron oxidant. Rate of reaction increases with decrease in dielectric constant. A suitable mechanism for the reaction was postulated.
\end{abstract}

Keywords: Kinetic study, Isopropyl alcohol, IPA, Oxalic acid, Pyridinium flourochromate, MichaelisMenten plot

\section{Introduction}

PFC is one of the most versatile oxidizing agents. A number of reports on the oxidation of several substrates by pyridinium flourochromate are available in the literature like oxidation of aromatic and aliphatic aldehydes ${ }^{1-4}$, oxidation of lactic acid ${ }^{5}$, oxidation of substituted toluenes $^{6}$, substituted aliphatic and aromatic alcohols ${ }^{7-8}$ etc.

Oxalic acid is available in immune system of human to fight against cancer disease, viral, bacterial and vascular conditions. Oxalic acid is an example of organic catalyst like enzyme because it catalyzes oxidation of isopropyl alcohol and not toxic for our body. Our literature survey reveals that the co-oxidation of isopropyl alcohol with oxalic acid by PFC in water medium has received a limited attention so we were particularly interested to see the mechanism of co-oxidation of isopropyl alcohol with oxalic acid by PFC in acid-water medium. 


\section{Experimental}

In the present work, oxalic acid and isopropyl alcohol analytical grade (SRL) was used as supplied (purity was checked by its melting point and boiling point) and double distilled water was used for preparing the solutions. Perchloric acid was prepared by diluting known volume of acid in double distilled water. The prepared solution was standardized by titration with previously standardized sodium hydroxide using phenolphthalein as an indicator. PFC was prepared as given in literrature ${ }^{9}$ and purity was checked by iodometrically.

\section{Method}

The reaction was carried out under pseudo first order conditions at $303 \mathrm{~K}$. The reaction was initiated by mixing thermally equilibrated solution of PFC, IPA and OA which also contained the required quantities of perchloric acid. PFC solution in water obeys Lambert Beer law. The reaction was followed by monitoring decrease in the absorbance of PFC at $354 \mathrm{~nm}$ by spectrophotometer. The kinetic runs were followed for more than $70 \%$ completion of reaction and good first order kinetics was observed. Pseudo-first order rate constants $\left(\mathrm{k}_{\mathrm{obs}}\right)$ were obtained from the slope of plot of log absorbance versus time. All kinetic studies carried out in three parts:

(i). Kinetic study of oxidation of IPA by PFC

(ii). Kinetic study of oxidation of oxalic acid by PFC

(iii).Kinetic study of co-oxidation of mixture (IPA + oxalic acid) by PFC

\section{Stoichiometry and product analysis}

The stoicheometry of the reaction was determined by performing the experiment at $303 \mathrm{~K}$, under the condition of [PFC] $>$ [isopropyl alcohol] and [oxalic acid] containing $0.5 \mathrm{M}$ $\left[\mathrm{HClO}_{4}\right]$ in water. When the reaction was completed, the PFC consumption was assayed by measuring the absorbance at $354 \mathrm{~nm}$. The initial concentration of PFC is $11.00 \times 10^{-4}$ and finial concentration of PFC is $8.00 \times 10^{-4}$. The consumption show that reaction exhibited 3:2 stoicheometry with respect to IPA i.e. Three mole of IPA consumed two moles of PFC. Stoichiometric equation for oxidation of oxalic acid is not predictable because of complex reaction between oxalic acid and $\mathrm{PFC}^{10}$. The qualitative product study was made under kinetic conditions. The main reaction product was identified as acetone from IPA and carbon dioxide from oxalic acid. Product acetone proved by its 2,4-dinitrophenylhydrazine derivative and Fehling solution. Product $\mathrm{CO}_{2}$ proved by lime water test. $\mathrm{Cr}(\mathrm{III})$ was confirmed by the UV-Visible spectra of the solution after completion of the reaction $\left(\lambda_{\max }=547 \mathrm{~nm}\right)$

\section{Results and Discussion}

\section{Stability of pyridinium flourochromate}

The solution of PFC in water obeys Lambert-Beer's Law at $\lambda_{\max }=354 \mathrm{~nm}$. There was no change in optical density and spectra of PFC solution under kinetic conditions, without substrate in water on long standing or heating up to $335-345 \mathrm{~K}$.

\section{Effect of PFC}

At constant $\left[\mathrm{HClO}_{4}\right]$, temperature and [oxalic acid] [IPA], plot of log [PFC] against time was linear indicating first-order dependence of the rate on PFC. the observed rate constant $\left(\mathrm{k}_{\mathrm{obs}}\right)$ was not affected by a change in initial concentration of PFC (Table 1). Rate $\alpha[\mathrm{PFC}]^{1}$. 
Table 1. Variation of rate with PFC concentrations

Temp $=303 \mathrm{~K},[\mathrm{IPA}]=1.0 \times 10^{-2} \mathrm{M},[\mathrm{OA}]=1.0 \times 10^{-2} \mathrm{M}$, Solvent $=$ water $\left[\mathrm{H}^{+}\right]=1.0 \mathrm{M}$, for
IPA \& $\left[\mathrm{H}^{+}\right]=0.5 \mathrm{M}$ for OA and Mixtue of OA+IPA

\section{Effect of substrate}

The rate of oxidation increased with increasing concentration of substrate (Table 2). Plot of $\log \mathrm{k}_{\mathrm{obs}}$ versus $\log$ [substrate] is straight line and slope value equal to ' $\mathrm{n}$ ' i.e. order of reaction with respect to [substrate].

Table 2. Variation of rate with substrates concentrations

Temp $=303 \mathrm{~K},[\mathrm{PFC}]=1.0 \times 10^{-3} \mathrm{M}$, Solvent $=$ water $\left[\mathrm{H}^{+}\right]=1.0 \mathrm{M}$, for IPA $\&\left[\mathrm{H}^{+}\right]=0.5 \mathrm{M}$ for $\mathrm{OA}$ and Mixture of $\mathrm{OA}+\mathrm{IPA}$

\begin{tabular}{cccc}
\hline S. No & IPA concentration, $M$ & Oxalic acid concentration, $\mathrm{M}$ & $\mathrm{k}_{\text {obs }} \times 10^{5} \mathrm{~s}^{-1}$ \\
\hline 1 & 0.008 & - & 10.59 \\
2 & 0.010 & - & 12.63 \\
3 & 0.014 & - & 16.90 \\
4 & 0.020 & - & 25.44 \\
5 & 0.025 & - & 28.71 \\
6 & 0.030 & - & 35.52 \\
7 & 0.040 & - & 54.50 \\
8 & - & 0.008 & 2.62 \\
9 & - & 0.010 & 5.73 \\
10 & - & 0.014 & 7.36 \\
11 & - & 0.020 & 13.62 \\
12 & - & 0.025 & 19.66 \\
13 & - & 0.030 & 27.83 \\
14 & - & 0.040 & 48.41 \\
15 & 0.008 & 0.010 & 143.22 \\
16 & 0.010 & 0.010 & 196.05 \\
17 & 0.014 & 0.010 & 260.63 \\
18 & 0.020 & 0.010 & 372.65 \\
19 & 0.025 & 0.010 & 466.02 \\
20 & 0.030 & 0.010 & 557.31 \\
21 & 0.040 & 0.010 & 732.04 \\
22 & 0.010 & 0.008 & 153.22 \\
23 & 0.010 & 0.014 & 254.05 \\
24 & 0.010 & 0.020 & 323.42 \\
25 & 0.010 & 0.025 & 380.52 \\
26 & 0.010 & 0.030 & 543.95 \\
27 & 0.010 & 0.040 & 712.82 \\
\hline
\end{tabular}


Linear relationship was observed. Hence order with respect to IPA in oxidation of IPA is one, order with respect to OA is one half in oxidation of oxalic acid, order with respect to of IPA is one in co-oxidation of IPA+OA and order with respect to OA is also one in cooxidation of IPA+OA (Figure 1). The plot of $1 / \mathrm{k}_{\mathrm{obs}}$ vs. 1/[oxalic acid] (Figure 2) gives straight line with small positive intercept, which indicates that Michaelis-Menten type kinetics is followed with respect to oxalic acid. Small intercept value indicates formation of complex which may be highly reactive.

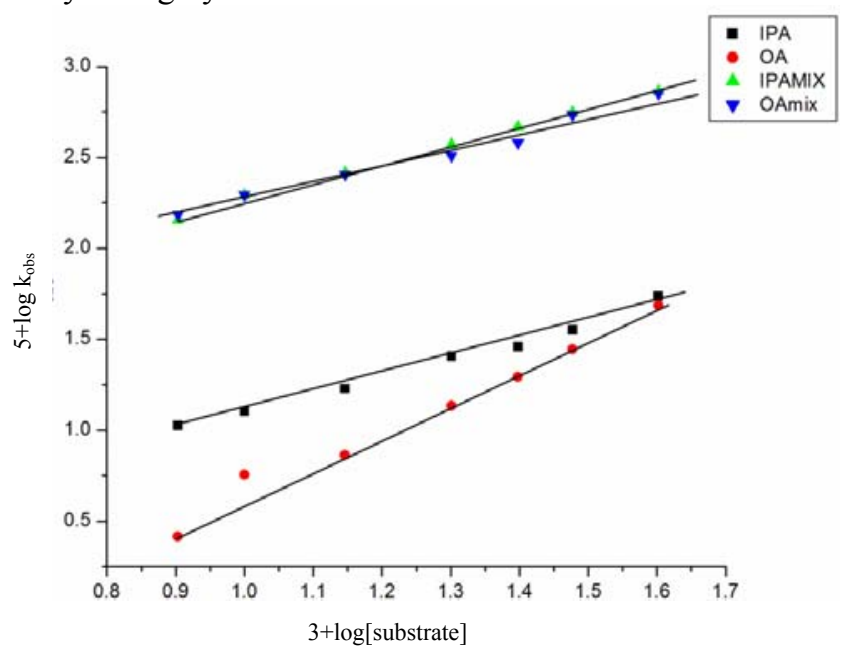

Figure 1. Effect of substrate concentration on rate of oxidation of IPA, OA and co-oxidation of IPA $+\mathrm{OA}$ by PFC (plot $\log \mathrm{k}_{\mathrm{obs}}$ vs. $\log$ [Substrate])

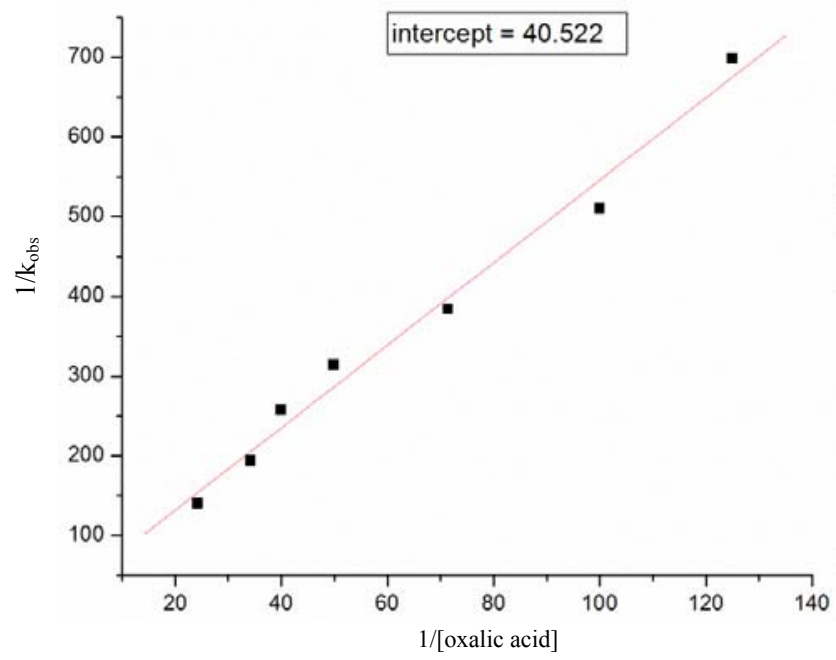

Figure 2. Michaelis-Menten plot $1 / \mathrm{k}_{\text {obs }}$ versus $1 /$ [oxalic acid] (oxidation of oxalic acid by PFC)

\section{Effect of perchloric acid}

Perchloric acid has been used as a source of $\mathrm{H}^{+}$ion in reaction medium. The concentration of perchloric acid was varied in the range 0.20-1.00 $\mathrm{M}$ keeping all other reactant concentration as constant at $303 \mathrm{~K}$ and the rates were measured for all three sets (Table 3 ). 
The acid catalyzed nature of this oxidation is confirmed by an increase in the rate, on addition of perchloric acid. The plot of $\log \mathrm{k}_{\mathrm{obs}}$ versus $\log \left[\mathrm{H}^{+}\right]$is a straight line with a slope $2.026($ order $=2)$ for oxidation of IPA, 0.468 (order $=0.5)$ for oxidation of oxalic acid and 0.557 (order $=0.5$ ) for co-oxidation of IPA and oxalic acid (Figure 3). Rate $\alpha\left[\mathrm{H}^{+}\right]^{\mathrm{n}}$ here ' $\mathrm{n}$ ' is order which was found from slope of $\log \mathrm{k}_{\mathrm{obs}} v s . \log \left[\mathrm{H}^{+}\right]$plot. $\Delta \mathrm{k}_{\text {obs }}$ (catalysis) also calculated. Increase in rate of oxidation on increase $\left[\mathrm{HClO}_{4}\right]$ suggests protonated PFC is more reactive and takes part in reaction. Similar observations were also reported by Hiran ${ }^{11-14}$. When we apply Zucker-Hammette hypothesis ${ }^{15}$ we find solvent is acting as proton abstractor agent in rate determining step.

Table 3. Variation of rate with perchloroic acid concentrations Temp $=303 \mathrm{~K}$,

$$
[\mathrm{IPA}]=1.0 \times 10^{-2} \mathrm{M},[\mathrm{OA}]=1.0 \times 10^{-2} \mathrm{M},[\mathrm{PFC}]=1.0 \times 10^{-3} \mathrm{M} \text { Solvent }=\text { water }
$$

\begin{tabular}{ccccc}
\hline $\begin{array}{c}\text { Concentration } \\
\text { of }\left[\mathrm{H}^{+}\right] \text {ion, } \mathrm{M}\end{array}$ & $\begin{array}{c}\mathrm{k}_{\text {obs }} \times 10^{5} \\
(\text { for IPA }) \mathrm{s}^{-1}\end{array}$ & $\begin{array}{c}\mathrm{k}_{\text {obs }} \times 10^{5} \\
(\text { for oxalic acid) } \\
\mathrm{s}^{-1}\end{array}$ & $\begin{array}{c}\mathrm{k}_{\text {obs }} \times 10^{5}(\text { for IPA+ } \\
\text { oxalic acid }) \mathrm{s}^{-1}\end{array}$ & $\begin{array}{c}\mathrm{k}_{\text {obs }} \times 10^{5} \\
\left(\Delta \mathrm{k}_{\text {catalysis }}\right) \mathrm{s}^{-1}\end{array}$ \\
\hline 0.20 & 1.63 & 3.65 & 119.80 & 114.52 \\
0.30 & 2.00 & 4.39 & 150.52 & 144.13 \\
0.40 & 2.41 & 5.14 & 177.75 & 170.20 \\
0.50 & 3.67 & 5.72 & 196.00 & 186.61 \\
0.60 & 4.79 & 5.98 & 222.23 & 211.46 \\
0.80 & 8.55 & 6.87 & 247.75 & 232.33 \\
1.00 & 11.24 & 7.94 & 301.96 & 282.78 \\
\hline
\end{tabular}

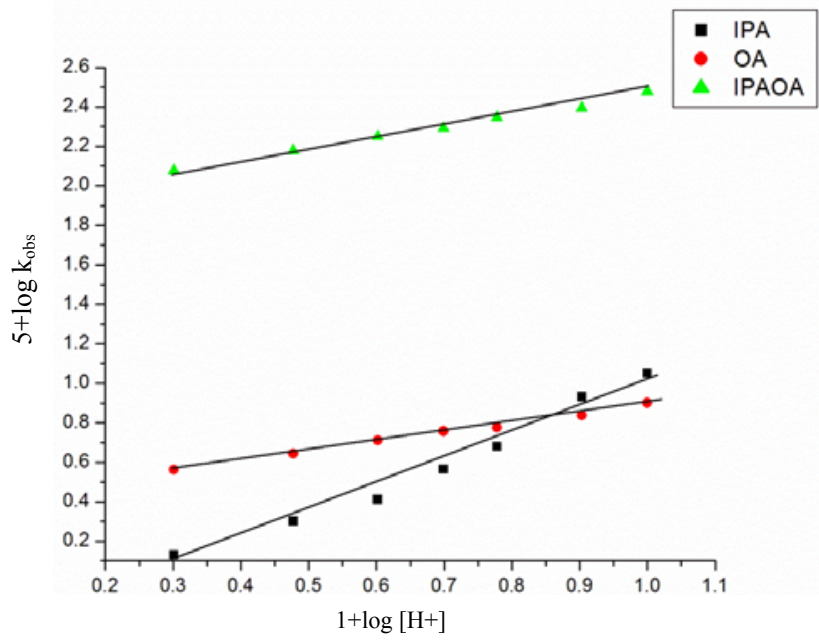

Figure 3. Effect of $\left[\mathrm{H}^{+}\right]$on rate of oxidation of IPA, OA and IPA+OA by PFC (plot log $\mathrm{k}_{\mathrm{obs}}$ vs. $\left.\log \left[\mathrm{H}^{+}\right]\right)$

\section{Effect of ionic strength}

To determine interaction in rate determining step, effect of ionic strength or rate was studied. Table 4 shows the effect of ionic strength on rate of reaction, but we found there was no effect of $\mathrm{Na}^{+}$and $\mathrm{ClO}_{4}^{-}$observed on rate of reaction in Debay Hukle limit i.e. $1.0 \times 10^{-3}$ to $10.0 \times 10^{-3} \mathrm{M}$. It proves that interaction in the rate determining step is not ion-ion type and one of the reactant molecules is dipole in nature ${ }^{16}$. 
Table 4. Variation of rate with sodium perchalorate concentration

\begin{tabular}{|c|c|c|c|c|}
\hline S.No. & $\begin{array}{c}\text { Conc. Of } \mathrm{NaClO}_{4} \\
\text { M }\end{array}$ & $\begin{array}{l}\mathrm{k}_{\mathrm{obs}} \times 10^{5} \\
\left(\text { IPA) } \mathrm{s}^{-1}\right.\end{array}$ & $\begin{array}{c}\mathrm{k}_{\text {obs }} \times 10^{5} \\
\text { (oxalic acid) } \mathrm{s}^{-1}\end{array}$ & $\begin{array}{c}\mathrm{k}_{\mathrm{obs}} \times 10^{5}(\mathrm{IPA}+ \\
\text { oxalic acid) } \mathrm{s}^{-1}\end{array}$ \\
\hline 1 & 0.0010 & 11.69 & 5.96 & 195.80 \\
\hline 2 & 0.0014 & 12.36 & 5.75 & 196.32 \\
\hline 3 & 0.0020 & 11.24 & 6.04 & 196.98 \\
\hline 4 & 0.0033 & 10.63 & 5.82 & 195.62 \\
\hline 5 & 0.0050 & 12.28 & 6.31 & 195.92 \\
\hline 6 & 0.0100 & 11.34 & 6.15 & 196.54 \\
\hline
\end{tabular}

\section{Effect of solvent concentration}

The influence of solvent polarity was studied in water-DMF mixture to find out involvement of ion-dipole or dipole-dipole in rate determining step. The DMF $\%(\mathrm{v} / \mathrm{v})$ was varied from $0 \%$ to $25 \%$ at fixed ionic strength, [IPA], [Oxalic acid] [PFC], $\left[\mathrm{H}^{+}\right]$and temperature (Table 5). The rate of oxidation increases with decrease in dielectric constant suggesting that a medium of low dielectric constant favors the oxidation process. The plot of $\log \mathrm{k}_{\mathrm{obs}}$ versus $1 / \mathrm{D}$ (dielectric constant) is linear with positive slope (Figure 5) suggesting the presence of either dipole-dipole or ion-dipole type of interaction between the oxidant and the substrate (Scatchard 1932, 1939) ${ }^{17-18}$. Plot of log $\mathrm{k}_{\text {obs }}$ versus $(\mathrm{D}-1) /(2 \mathrm{D}+1)$ is a curvature (Figure 6) indicating the absence of dipoledipole interaction in the rate determining step. Positive slope of log $\mathrm{k}_{\mathrm{obs}}$ versus $1 / \mathrm{D}$ plot indicates that the reaction involves a cation-dipole type of interaction in the rate determining step.

Table 5. Variation of rate with DMF concentration

Temp $=303 \mathrm{~K},[\mathrm{IPA}]=1.0 \times 10^{-2} \mathrm{M},[\mathrm{OA}]=1.0 \times 10^{-2} \mathrm{M},[\mathrm{PFC}]=1.0 \times 10^{-3},\left[\mathrm{H}^{+}\right]=1.0 \mathrm{M}$, for IPA $\&\left[\mathrm{H}^{+}\right]=0.5 \mathrm{M}$, for $\mathrm{OA}$ and Mixture of $\mathrm{OA}+\mathrm{IPA}$

\begin{tabular}{ccccccc}
\hline $\begin{array}{c}\text { Water : } \\
\text { DMF } \\
\%(\mathrm{~V} / \mathrm{V})\end{array}$ & Dmix & $1 / \mathrm{D}$ & $\begin{array}{c}(\mathrm{D}-1) \\
/(2 \mathrm{D}+1)\end{array}$ & $\begin{array}{c}\mathrm{k}_{\text {obs }} \times 10^{+5} \\
(\mathrm{IPA}) \mathrm{s}^{-1}\end{array}$ & $\begin{array}{c}\mathrm{k}_{\text {obs }} \times 10^{+5} \\
(\text { oxalic acid) } \\
\mathrm{s}^{-1}\end{array}$ & $\begin{array}{c}\mathrm{k}_{\text {obs }} \times 10^{+5} \\
\left(\mathrm{IPA}+\text { oxalic }^{-5}\right. \\
\mathrm{acid}^{-1}\end{array}$ \\
\hline 100:00 & 80.00 & 0.01250 & 0.49068 & 11.24 & 5.72 & 196.08 \\
$95: 05$ & 79.47 & 0.01258 & 0.49062 & 25.05 & 27.66 & 197.75 \\
$90: 10$ & 78.90 & 0.01267 & 0.49055 & 36.95 & 41.05 & 228.38 \\
$85: 15$ & 78.28 & 0.01277 & 0.49048 & 49.93 & 54.05 & 270.56 \\
$80: 20$ & 77.60 & 0.01288 & 0.49039 & 60.64 & 67.92 & 304.80 \\
$75: 25$ & 76.86 & 0.01301 & 0.49030 & 73.50 & 85.10 & 334.24 \\
\hline
\end{tabular}

\section{Test of free radical}

Stabilizer free radical acrylonitrile was added to reaction mixture in $\mathrm{N}_{2}$ atmosphere. Neither decrease in rate of reaction nor milky appearance was observed. This proved that free radical was not take part in this oxidation. This also proved that $\mathrm{Cr}(\mathrm{VI})$ is neither one nor three electron oxidant in these oxidation. 


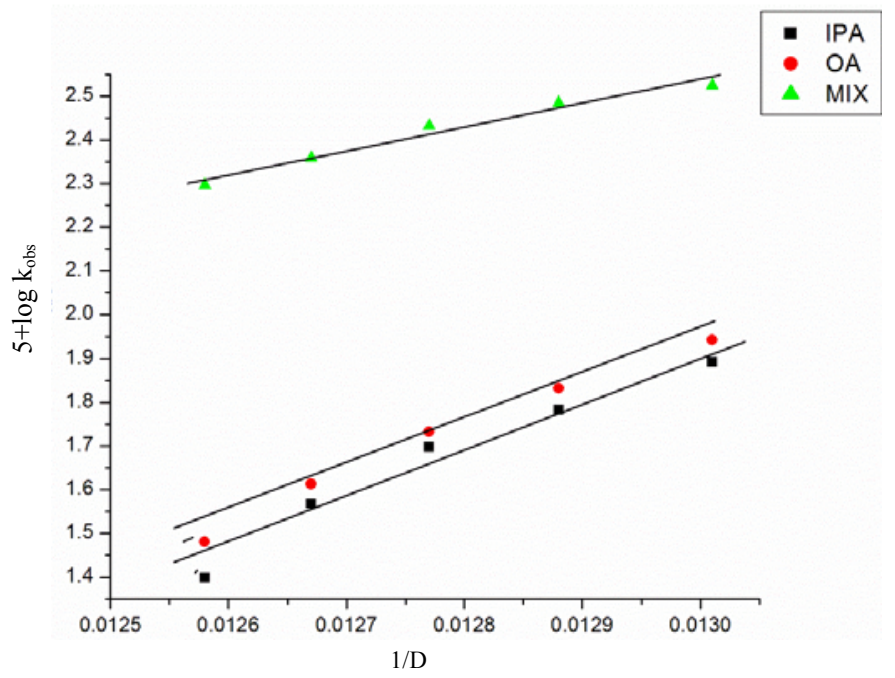

Figure 5. plot of $\log \mathrm{k}_{\mathrm{obs}}$ versus 1/D.

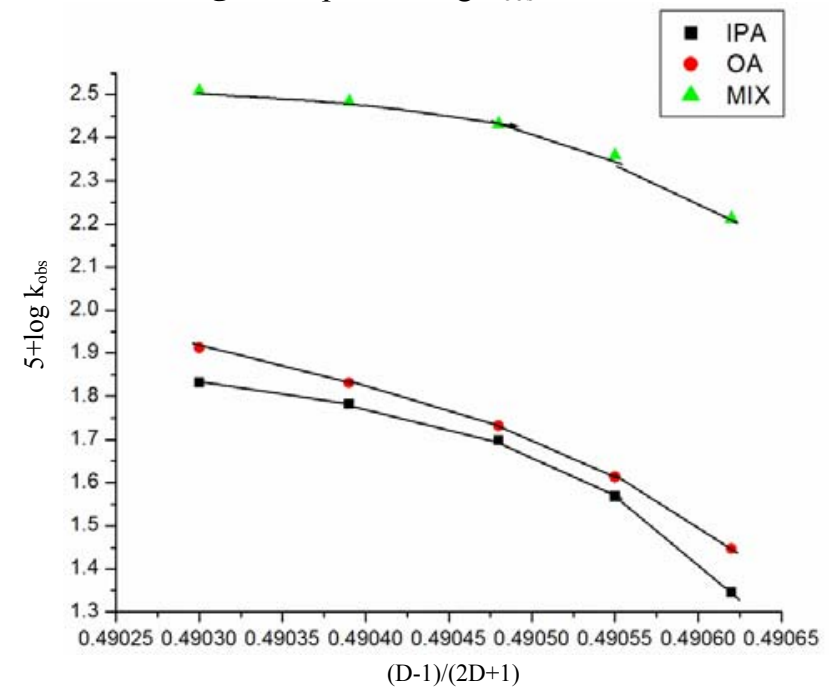

Figure 6. Plot of $\log \mathrm{k}_{\mathrm{obs}}$ versus $(\mathrm{D}-1) /(2 \mathrm{D}+1)$

\section{Effect of temperature}

The rate of oxidation of IPA, oxalic acid and mixture of both compounds (IPA + oxalic acid) were determined at different temperature range from 303 to $323 \mathrm{~K}$ to calculate the rate constants (Table 6) and various thermodynamic parameters (Table 7). A plot of log $\mathrm{k}_{\mathrm{obs}}$ versus $1 / \mathrm{T}$ (inverse of absolute temperature) is a straight line with negative slope (Figure 7). This shows that Arrhenius Equation is valid for this oxidation. Energy of activation was calculated by slope and it was found $67.55 \mathrm{~kJ} \mathrm{~mol}^{-1}$ for IPA \& $44.51 \mathrm{~kJ} \mathrm{~mol}^{-1}$ for EDTA and $31.59 \mathrm{~kJ} \mathrm{~mol}^{-1}$ for (IPA + EDTA). It proves that rate of reaction increases when both compounds taken together, means one of them is acting as a catalyst. Decrease in energy of activation suggests catalytic root of oxidation. 
Table 6. Variation of rate with temperature

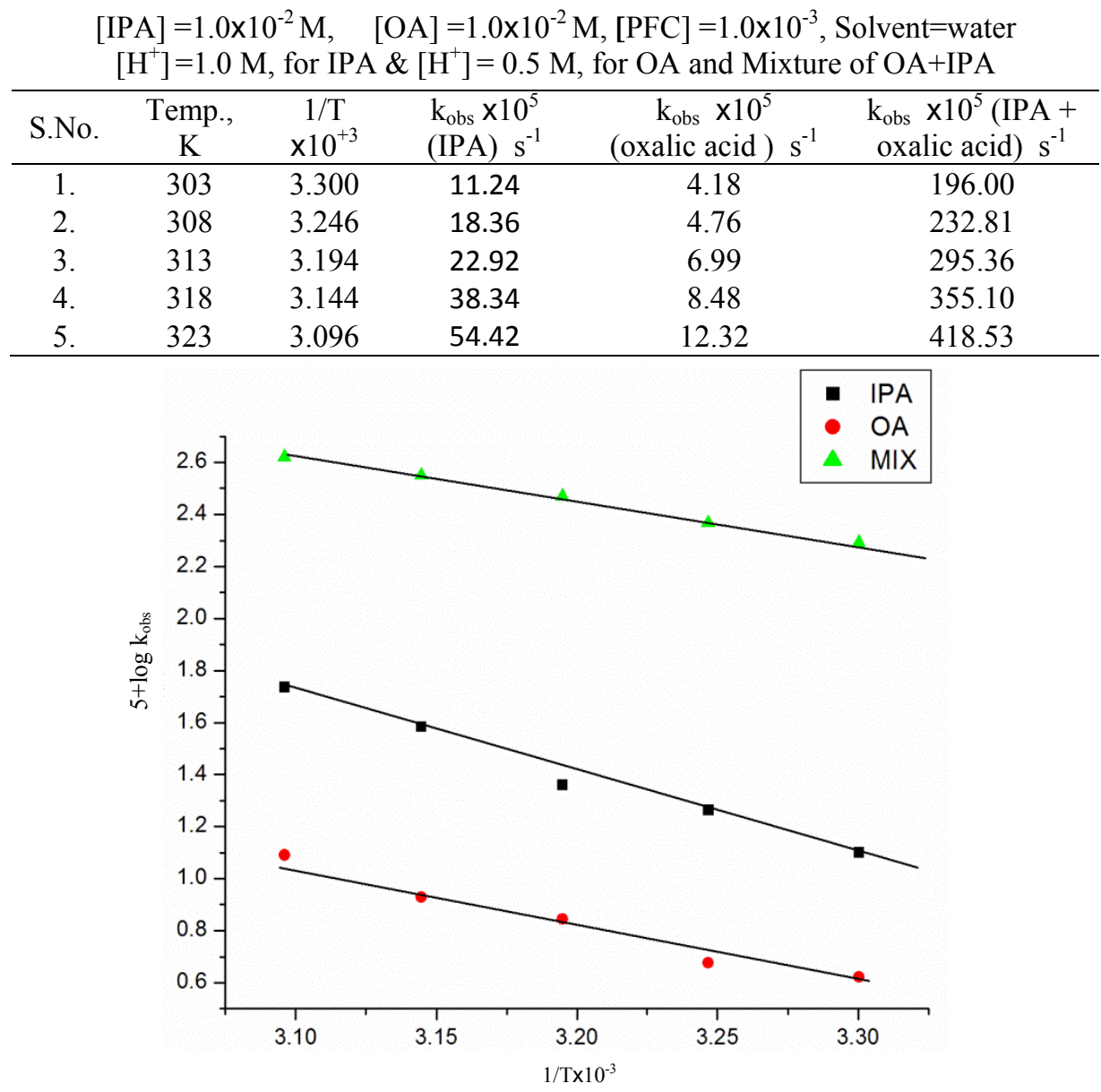

Figure 7. Effect of temperature on rate of oxidation of IPA, OA, and IPA+OA by PFC

\section{Thermodynamics parameters}

With the help of activation energy various thermodynamic parameters like entropy of activation, enthalpy of activation and free energy of activation evaluated as given in Table 7. Energy of activation for co-oxidation is quite lower than individual proved catalysis. Large negative entropy suggests reactions are slow ${ }^{19}$.

Table 7. Thermodynamic parameters

\begin{tabular}{lcccc}
\hline Substrate & $\begin{array}{c}\text { Energy of } \\
\text { activation }\left(\Delta E_{a}^{\#}\right) \\
\mathrm{kJ} \mathrm{mol}^{-1}\end{array}$ & $\begin{array}{c}\text { Entropy } \\
\left(\Delta \mathrm{S}^{\#}\right) \mathrm{J} \mathrm{mol}^{-1} \mathrm{~K}^{-1}\end{array}$ & $\begin{array}{c}\text { Enthalpy } \\
\left(\Delta \mathrm{H}^{\#}\right) \mathrm{kJmol}^{-1}\end{array}$ & $\begin{array}{c}\text { Free energy } \\
\left(\Delta \mathrm{G}^{\#}\right) \mathrm{kJmol}^{-1}\end{array}$ \\
\hline IPA & $67.55 \pm 0.66$ & $-309.75 \pm 3.00$ & $65.05 \pm 0.65$ & $91.26 \pm 0.90$ \\
Oxalic acid & $44.51 \pm 0.66$ & $-251.50 \pm 3.00$ & $42.01 \pm 0.65$ & $73.64 \pm 1.09$ \\
IPA+ & $31.59 \pm 0.16$ & $-298.75 \pm 1.50$ & $29.09 \pm 0.15$ & $93.07 \pm 0.47$ \\
Oxalic acid & & & & \\
\hline
\end{tabular}




\section{Mechanism}

On the basis of above experimental results following mechanism has been given
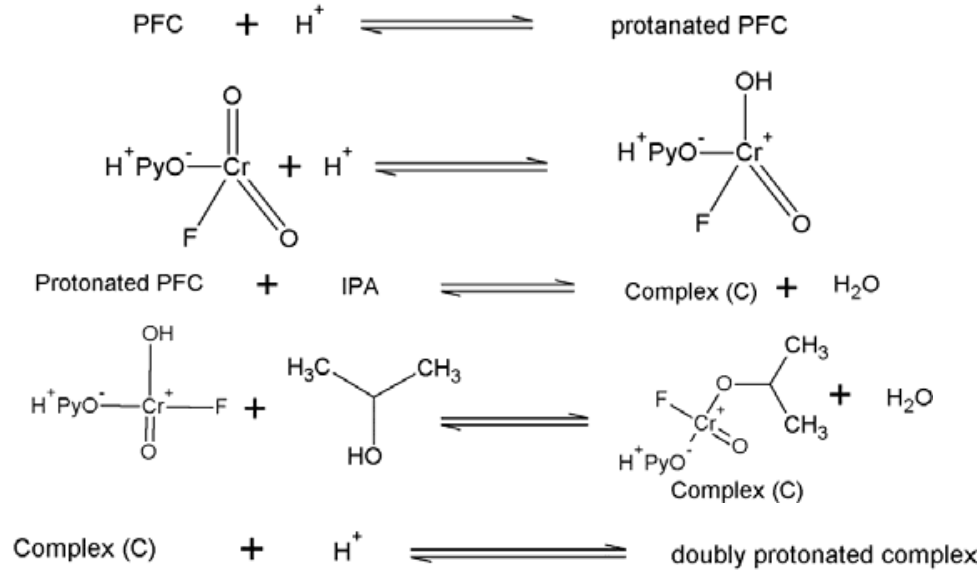<smiles></smiles><smiles>CC(C)O[C+](O)([18OH])F</smiles>

doubly protonated complex

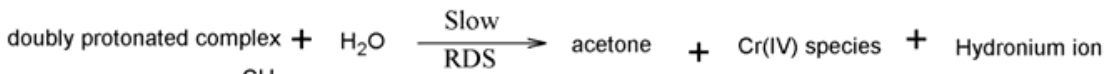

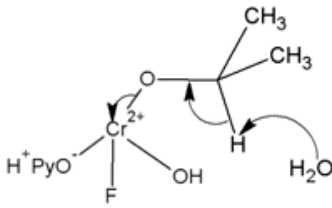<smiles>[R6][C@H](C)[C@H](C)C(C)=O</smiles>

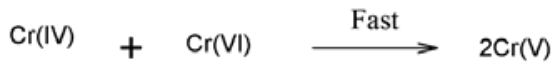<smiles>CC(C)=O</smiles>

So the overall reaction is:

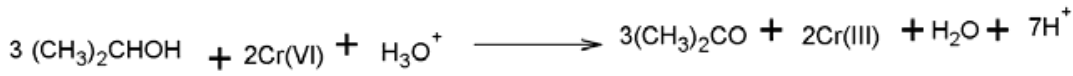

Scheme 1. Mechanism of oxidation of IPA with PFC

(1) $\mathrm{PFC}+\mathrm{H}^{+}$<smiles>O=[Cr](=O)(F)[Po+]</smiles>

Protonated PFC<smiles>O=[Cr]([O+])(O)F</smiles> 


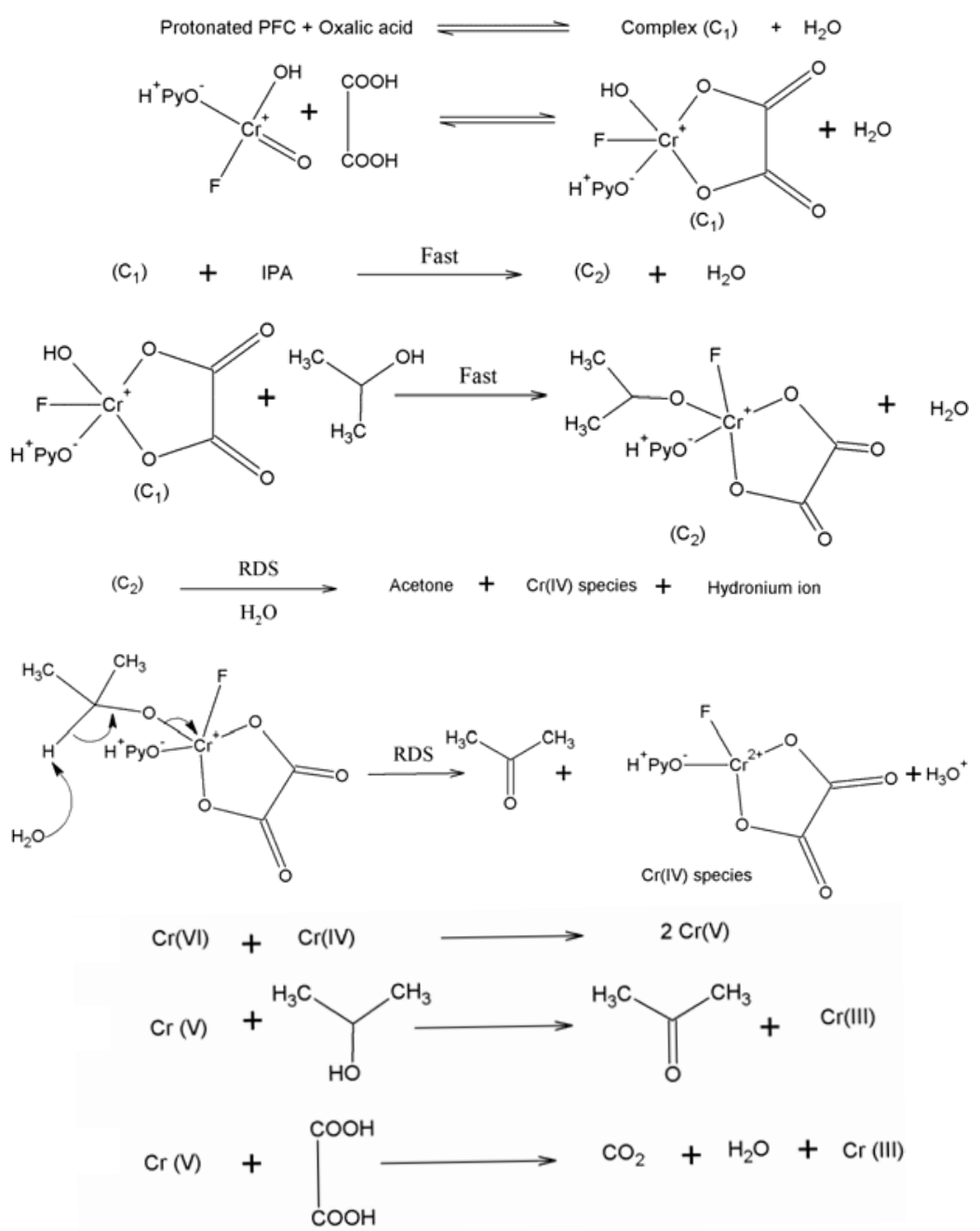

Scheme 2. Mechanism of co-oxidation of IPA and oxalic acid with PFC

\section{References}

1. Hiran B L, Khuntwal J and Malkani R K, Oxidation Communication, 2013, 36(3), 612-625.

2. Agarwal A, Choudhary K and Banerji K K, J Chem Res., 1990, 86(S).

3. Agarwal A, Chaudhary K and Banerji K K, J Org Chem., 1991, 56(11), 5111-5113; DOI:10.1021/jo00017a023

10. Hiran B L, Khuntwal J, Malkani R K and Singh D, Arabian J Chem., Online available 2 June 2011,

4. Zaheer S, Ahmed S, Syed S and Mansoor S S, Adv Appl Sci Res., 2012, 3 (1), 123-129.

5. Bhattacharjee B, Bhattacharjee M N and Bhattacharjee A K, Bull Chem Soc Jpn., 1986, 59(10), 3217-3221; DOI:10.1246/bcsj.59.3217

6. Banerji K K, J Chem Soc Perkins Trans., 1988, 2, 547-549; DOI:10.1039/ P29880000547 
7. Banerji K K, J Chem Soc Perkins Trans., 1988, 2, 2065-2069; DOI:10.1039/ P29880002065

8. Bhattacharjee M N, Choudhari M K, Dasgupta H S, Roy N and Khathing D T, Synthesis, 1982, 1(7), 588-590; DOI:10.1055/s-1982-29872

11. Khan Z, Raju and Kabir-ud-Din, Indian J Chem B, 2004, 43(B), 149-156.

12. Hiran B L, Joshi V, Choudhary J, Shorgar N and Verma P, Int J Chem Sci., 2004, 2(2), 164-170.

13. Hiran B L, Nalwaya N and Jain A, J Indian Chem Soc., 2002, 79(1), 587-589.

14. Hiran B L, Malkani R K, Choudhary P, Verma P and Shorgar N, Asian J Chem., 2007, 18(4), 3081-3086.

15. Hiran B L, Meena M L and Kunthwal J, Der Pharma Chemica, 2010, 2(5), 470-478.

16. Jain S, Hiran B L and Bhatt C V, J Chem., 2009, 6(1), 237-246; DOI:10.1155/2009/907071

17. Laidler K J, Chemical Kinetics, Third Ed., Pearson Education, New Delhi, 2005, 198.

18. Scatchard G J, Chem Phys., 1932, 10(2-3), 229-233; DOI:10.1016/03010104(75)87038-8

19. Scatchard G J, Chem Phys., 1939, 7, 657.

20. Glasstone S, Laidler K J and Erying H, The theory of rate Process. McGraw-Hill, New York (Chapters III and IV), 1941. 